\title{
Experimental model for in vivo determination of dietary fibre and its effect on the absorption of nutrients in the small intestine
}

\author{
BY ANN-SOFIE SANDBERG, H. ANDERSSON, B. HALLGREN, \\ KRISTINA HASSELBLAD AND B. ISAKSSON
}

Department of Clinical Nutrition

AND L. HULTÉN

Department of Surgery II, Sahlgren's Hospital, Göteborg, Sweden

(Received 16 June 1980 - Accepted 21 November 1980)

1. An experimental model for the determination of dietary fibre according to the definition of Trowell et al. (1976) is described. Food was subjected to in vivo digestion in ileostomy patients, and the ileostomy contents were collected quantitatively, the polysaccharide components of which were analysed by gas-liquid chromatography and the Klason lignin by gravimetric determination. The model was used for the determination of dietary fibre in AACC (American Association of Cereal Chemists), wheat bran and for studies on the extent of hydrolysis of wheat-bran fibre in the stomach and small intestine. The effect of wheat bran on ileostomy losses of nitrogen, starch and electrolytes was also investigated.

2. Nine patients with established ileostomies were studied during two periods while on a constant low-fibre diet. In the second period $16 \mathrm{~g} \mathrm{AACC}$ wheat bran/d was added to the diet. The ileostomy contents and duplicate portions of the diet were subjected to determinations of wet weight, dry weight, water content, fibre components, starch, $\mathbf{N}$, sodium and potassium.

3. The wet weight of ileostomy contents increased by $94 \mathrm{~g} / 24 \mathrm{~h}$ and dry weight by $10 \mathrm{~g} / 24 \mathrm{~h}$ after consumption of bran. The dietary fibre of AACC bran, determined as the increase in polysaccharides and lignin of ileostomy contents after consumption of bran, was $280 \mathrm{~g} / \mathrm{kg}$ fresh weight ( $310 \mathrm{~g} / \mathrm{kg}$ dry matter). Direct analysis of polysaccharides and lignin in bran gave a value of $306 \mathrm{~g} / \mathrm{kg}$ fresh weight. Of the added bran hemicellulose and cellulose $80-100 \%$ and $75-100 \%$ respectively were recovered in ileostomy contents. There was no significant difference between the two periods in amount of $N$, starch and $K$ found in the ileostomy contents. The $\mathrm{Na}$ excretion increased during the 'bran' period and correlated well with the wet weight of ileostomy contents.

4. In conclusion, it seems probable that determination of dietary fibre by in vivo digestion in ileostomy patients comes very close to the theoretical definition of dietary fibre, as the influence of bacteria in the ileum seems small. Bacterial growth should be avoided by using a technique involving the change of ileostomy bags every $2 \mathrm{~h}$ and immediate deep-freezing of the ileostomy contents. True dietary fibre can be determined by direct analysis of polysaccharides and lignin in the food, at least in bran. Very little digestion of hemicellulose and cellulose from bran occurs in the stomach and small bowel. The 10-20\% loss in some patients may be due to digestion by the gastric juice or to bacterial fermentation in the ileum, or both. The extra amount of faecal $\mathbf{N}$ after consumption of bran, reported by others, is probably produced in the large bowel.

Wheat bran, a part of the wheat grain is rich in hemicellulose, cellulose and lignin. It has been used in many studies for evaluating the effects of dietary fibre. Physiological assays in man have shown a number of effects such as increase in stool weight (Eastwood et al. 1973; Findlay et al. 1974; Eastwood et al. 1978), faecal fat and nitrogen excretion (McCance \& Glaser, 1948; McCance \& Walsham, 1948; Walker, 1975; Cummings et al. 1976), decreased transit time (Harvey et al. 1973; Findlay et al. 1974; Kirwan et al. 1974; Payler et al. 1975; Eastwood et al. 1978; Andersson et al. 1979) and interference with mineral absorption in short-term studies (Rheinhold et al. 1973; Jenkins et al. 1975; Rheinhold et al. 1976; Cummings et al. 1976). The digestion of bran has been investigated by Southgate (1973) and Southgate et al. (1976), who concluded that at least half the fibre is digested in the gut, most probably by the colonic microflora. Whether or not digestion of fibre from bran also occurs in the stomach and small bowel, and if so to what extent, is unknown. Based on physiological considerations (Trowell et al. 1976), dietary fibre is defined as plant 
polysaccharides and lignin which are resistant to hydrolysis by the alimentary enzymes of man.

The aim of the present investigation was to determine dietary fibre according to the physiological definition (Trowell et al. 1976). For this purpose an experimental model was developed using in vivo digestion of bran in volunteers with established ileostomies. It was considered of particular interest to study in more detail whether or not hemicellulose, cellulose and lignin from bran perhaps are digested in the stomach and small bowel and whether or not bran might have any effect on ileal nitrogen and electrolyte excretion. The Ethical Committee of Sahlgren's Hospital has approved of the study.

\section{SUBJECTS AND METHODS}

\section{Subjects}

Nine patients, eight men and one woman (mean age $41 \cdot 7$ years, range 25-52 years), previously (4 months to 2 years), proctocolectomized for ulcerative colitis and with established ileostomies volunteered to take part in the study. Only a very short length of the terminal ileum had been removed, the ileostomies functioned properly and the volumes of excreta were within normal range, without the use of drugs to reduce ileal stoma volume. The patients were hospitalized for treatment of persisting perineal sinuses but were otherwise in excellent condition, having completely recovered after surgery and working full-time. No general drug therapy was given, except for one patient who took Seloken (Hässle, $\beta$-adrenergic receptor antagonist). Only a conventional local treatment of the anorectal region was given including treatment with Varidase (Lederle, StreptokinaseStreptodornase preparation for enzymatic cleansing) in two patients.

\section{Experimental model}

The study on each patient extended over a period of 2 weeks at hospital. During four consecutive days during the first week (period 1), starting on Monday at lunchtime, ending on Friday morning after breakfast, the patients were given a constant low-fibre diet. The patients spent the weekend at home. The next week (period 2) the same regimen was followed except that the constant low-fibre diet was now supplemented with $16 \mathrm{~g}$ bran/d.

To investigate if the bran was excreted on the day of consumption or if excretion was delayed, a second study was carried out, in which three subjects were studied during ten consecutive days on a low-fibre diet supplemented with bran on days 5, 6 and 7 .

Diets

All the food for the subjects was prepared in the metabolic kitchen. The low-fibre diet consisted mainly of rice, fish or meat, white bread and icecream (Table 1). The same batches of fish, meat and icecream were used for all patients. A type of icecream low in alginates was used in the study. Meat and fish portions were stored at $-18^{\circ}$ after cooking, then thawed and heated in an oven for consumption. All patients took the same menu, except for lunch when they could have either fish or hamburger, throughout the two periods. The intake was kept constant on an individually selected energy level 6.3 (1500), 8.4 (2000), 10.5 (2500) MJ (kcal), to maintain energy balance. Nothing except items on the menu was allowed and particular care was taken that all food served was consumed.

AACC (American Association of Cereal Chemists) certified food grade wheat bran ( $R$ 07-3691) was used in the study, except for patient no. 1 who was given a Swedish commercial bran. In period $2,16 \mathrm{~g}$ bran was taken in separate doses during the day, mixed in rice (lunch, dinner) or in sandwiches. Duplicate portions of the diet were collected on the third day in each period. After addition of $10 \mathrm{ml}$ of emulsifier (DNS, disodiumoctylsulphosuccinate; $40 \mathrm{~g} / \mathrm{kg}$ ) and five drops of antifoaming agent (Silicon E 100), the total duplicate daily diet 
Table 1. Energy allowance $(\mathrm{g})$ of dietary ingredients

\begin{tabular}{lccc}
\hline Energy intake (MJ (kcal)) & $6 \cdot 3(1500)$ & $8 \cdot 4(2000)$ & $10 \cdot 5(2500)$ \\
\hline White bread & 50 & 100 & 150 \\
Margarine & 34 & 51 & 67 \\
Cheese & 30 & 60 & 120 \\
Ham & 40 & 40 & 40 \\
Minced beef* & 100 & 120 & 140 \\
Plaice* & 100 & 125 & 150 \\
Wheat flour & 4 & 5 & 6 \\
Golden breadcrumbs & 6 & 7 & 8 \\
Rice & 60 & 80 & 100 \\
Milk & 300 & 300 & 300 \\
Fillet of pork & 75 & 100 & 125 \\
Cream & 25 & 25 & 25 \\
Ice cream & 80 & 80 & 80 \\
Tea or coffee & - & - & - \\
\hline
\end{tabular}

- Subjects chose either plaice or minced beef for lunch.

Table 2. Composition $(\mathrm{g} / \mathrm{d})$ of low-fibre diet

\begin{tabular}{lccc}
\hline \hline Energy intake (MJ (kcal)) & $6 \cdot 3(1500)$ & $8 \cdot 4(2000)$ & $10 \cdot 5(2500)$ \\
\hline Calculated values* & & & \\
$\quad$ Water & 490 & 560 & 640 \\
Ash & 8 & 12 & 16 \\
Fat & 72 & 100 & 130 \\
Carbohydrates & 110 & 150 & 200 \\
Analytical values & & & \\
$\quad$ Protein (nitrogen x6.25) & 92 & 114 & 130 \\
$\quad$ Starch (114) & 98 & 113 & 127 \\
Other polysaccharides & $3 \cdot 3$ & $4 \cdot 5$ & $5 \cdot 2$ \\
Sodium (mmol) & 85 & 114 & 123 \\
Potassium (mmol) & 49 & 68 & 68 \\
\hline
\end{tabular}

- Calculated from food tables (The Swedish National Food Administration, 1978).

collections were homogenized in a Kenwood Major homogenizer on the following day. Half of each homogenate was subsequently frozen and stored at $-20^{\circ}$ until freeze-drying. All of the dried diets was ground by hand using a pestel and mortar. Nitrogen, sodium, potassium, starch and other polysaccharides were analysed. Other components given in Table 2 were calculated from food tables. Bran was analysed separately. Results are given in Table 3.

\section{Collection of ileostomy contents}

Ileostomy contents were collected the last $3 \mathrm{~d}$ in each period. For patients studied for ten consecutive days ileostomy contents were collected for $9 \mathrm{~d}$. The ileostomy bags were changed every $2 \mathrm{~h}$ during the day, just before bed and at 07.00 hours. The bags were immediately frozen on dry ice to avoid bacterial growth, weighed and stored at $-20^{\circ}$. The night bag was weighed separately. Ileostomy bags from each $24 \mathrm{~h}$ period ( 07.00 hours -07.00 hours) were allowed to thaw quickly on a warm water-bath, their contents combined as soon as possible, homogenized without addition of DNS or Silicon E 100, and all of the homogenate freeze-dried to constant weight. All of the dried ileostomy contents was ground in the same way as the diets. 
Table 3. Composition of wheat bran $(\mathrm{g} / \mathrm{kg}$ fresh weight)

\begin{tabular}{lcc}
\hline & AACC bran* & Swedish bran \\
\hline Moisture & 80 & 88 \\
Ethanol extractives & 135 & 141 \\
Polysaccharides (starch, & & \\
hemicellulose, cellulose) & 500 & 483 \\
Starch & 211 & 144 \\
Cellulose & 68 & 79 \\
Klason lignin & $44(19) \dagger$ & $69(30) \dagger$ \\
Protein & 165 & 146 \\
(nitrogen $\times 6 \cdot 31) \dagger$ & 51 & 57 \\
Ash & 51 & 57 \\
$\quad$ Polysaccharide composition (g anhydro sugar units/kg bran) \\
Rhamnose & Traces & - \\
Fucose & Traces & $\mathbf{8 3}$ \\
Arabinose & 70 & 153 \\
Xylose & 123 & 2 \\
Mannose & 2 & 6 \\
Galactose & 5 & 239 \\
Glucose & 297 & \\
\hline
\end{tabular}

* American Association of Cereal Chemists.

$\dagger$ Klason lignin in the acid detergent fibre residue.

$\ddagger$ Protein in bran calculated according to Food and Agriculture Organization of the United Nations (1970).

\section{Analytical methods}

Wet weight, dry weight and water content were calculated from the weights before and after freeze-drying. The dry weight and water content were corrected for the rest of water in freeze-dried material determined by oven-drying of $1 \mathrm{~g}$ aliquots at $105^{\circ}$ for $18 \mathrm{~h}$. Ash weight was determined after the dry-ashing of the freeze-dried sample at $450^{\circ}$ overnight, addition of a few drops of concentrated nitric acid and continued ashing under cover until a white or yellow residue remained. The ileostomy contents of each $24 \mathrm{~h}$ period were analysed.

Polysaccharides in ileostomy contents, diets and bran were determined by gas-liquid chromatography of the neutral polysaccharide constituents according to Theander \& Ȧman (1979) and lignin as Klason lignin (Fig. 1). Samples (5 g), freeze-dried and ground, were extracted with ethanol $(800 \mathrm{ml} / \mathrm{l}),\left(3 \times 50 \mathrm{ml}\right.$ at $100^{\circ}$ for $\left.20 \mathrm{~min}\right)$. The dry extracted sample was ground and duplicate samples of $1 \mathrm{~g}$ were hydrolysed (treated with $12 \mathrm{M}-\mathrm{H}_{2} \mathrm{SO}_{4}$ at room temperature for $2 \mathrm{~h}$ and refluxed after dilution to $0.358 \mathrm{M}-\mathrm{H}_{2} \mathrm{SO}_{4}$ for $6 \mathrm{~h}$ ), neutralized with $\mathrm{BaCO}_{3}$ and reduced with $\mathrm{KBH}_{4}$. The alditol mixture was decationized and the boric acid removed by adding methanol $(3 \times 2 \mathrm{ml})$ and evaporated to dryness. The alditols were acetylated with acetic anhydride - pyridine and the alditol acetates determined quantitatively by GLC. The analyses were performed in a Hewlett Packard gas chromatograph, HP 4710 A, with a flame ionization detector, fitted with glass columns containing $3 \%$ SP- 2340 on Suplecoport ( $100 / 120 \mathrm{mesh})$ at a constant oven temperature of $210^{\circ}$ and a nitrogen gas flow of $30 \mathrm{ml} / \mathrm{min}$. The peak areas were measured with an HP $3380 \mathrm{~A}$ Integrator. Myo-inositole was used as an internal standard; correction factors for hydrolysis and derivatization losses and gas-chromatographic response factors for the individual sugars were measured according to Bethge et al. (1971). The insoluble hydrolysis residue was filtered off on a glass filter (Pyrex No. 2), thoroughly washed with water and determined gravimetrically, after drying at $105^{\circ}$ for $18 \mathrm{~h}$, as Klason lignin.

Cellulose content in ileostomy contents and diets was determined by digestion with acid detergent according to Van Soest (1963) in a semi-automated system for analyses of fibre 


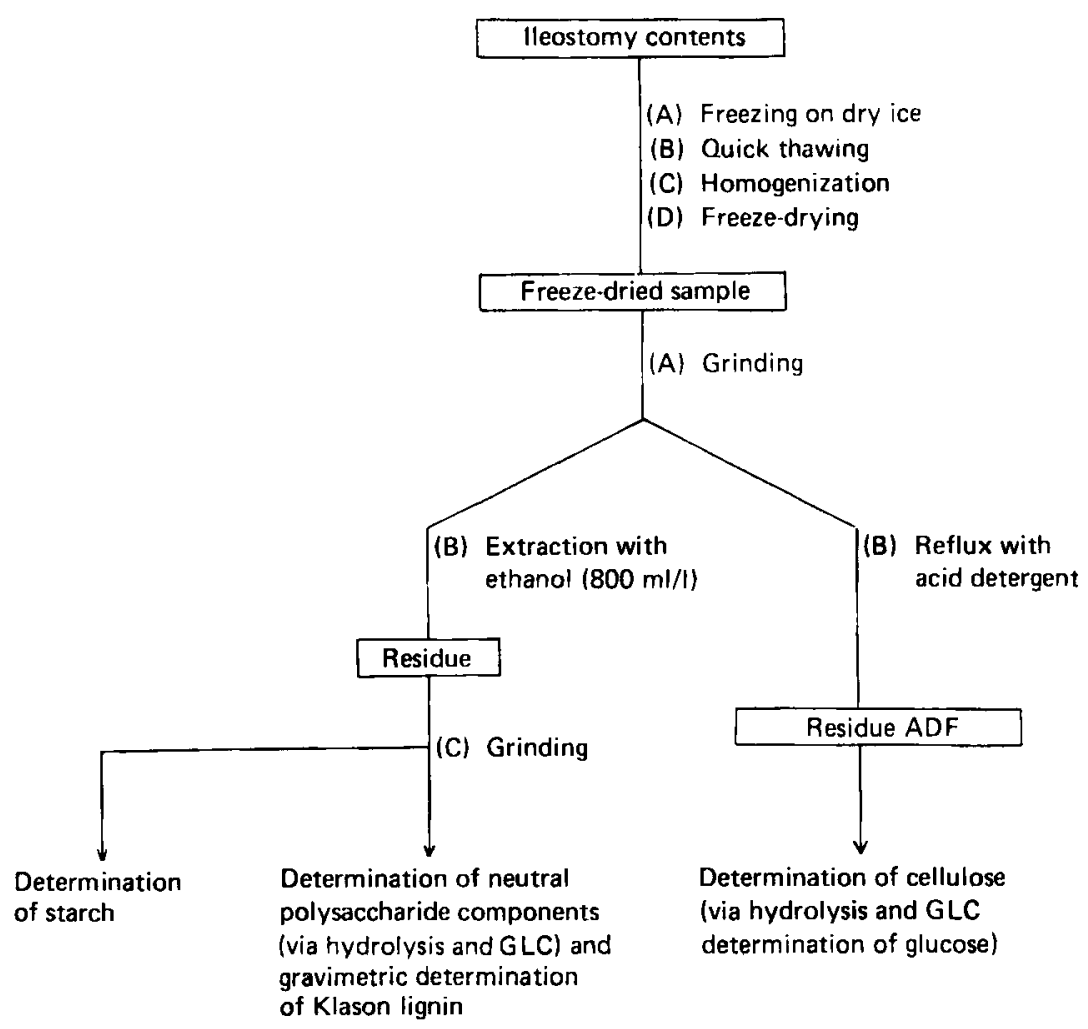

Fig. 1. Analytical procedures for in vivo determination of dietary fibre (ADF, acid detergent fibre, Van Soest, 1963; GLC - gas-liquid chromatography).

(Tecator Fibertec System) using celite to facilitate the filtration and gas-liquid chromatographic determination of glucose in the acid-detergent residue. Klason lignin in bran was determined both in hydrolysates from alcohol-extracted samples and in the acid-detergent residue, as it could be supposed to be less contaminated (Gordon, 1978). All analyses of hydrolysates were done in duplicate. Starch was analysed separately by digestion with amyloglucosidase and spectrophotometric determination of glucose according to the method of Larsson et al. (1979). The $\mathrm{N}$ content of the diet, bran and ileostomy contents was determined after acid digestion according to Per Tingvall (unpublished results; treatment with $\mathrm{H}_{2} \mathrm{SO}_{4}-\mathrm{H}_{3} \mathrm{PO}_{4}, 95: 5$ and addition of $1.3 \mathrm{~g} \mathrm{~K}_{2} \mathrm{SO}_{4}, 0.003 \mathrm{~g}$ anhydrous $\mathrm{CuSO}_{4}$ and $0.5 \mathrm{ml} \mathrm{H}_{2} \mathrm{O}_{2}$ at $405^{\circ}$ for 25 minutes. An additional $70 \mathrm{ml}$ water was added, the tubes equilibrated to room temperature, made to volume and mixed) and determination of ammonia based on the automated Technicon method (Marten \& Catanzaro, 1966). Na and $\mathrm{K}$ were determined after the wet-ashing of freeze-dried samples in $\mathrm{H}_{2} \mathrm{SO}_{4}$ and $\mathrm{H}_{2} \mathrm{O}_{2} 300 \mathrm{ml} / \mathrm{l}$ at $295^{\circ}$, dilution with $\mathrm{H}_{2} \mathrm{SO}_{4} 1 \mathrm{ml} / \mathrm{l}$ and the emission read against a blank in an Eppendorf flame-emission photometer. Equal concentrations of $\mathrm{H}_{2} \mathrm{SO}_{4}$ were used in sample, blank and standards. To the $\mathrm{Na}$ standard was added $\mathrm{KCl}$ approximately to the same amount as in the sample. The digest was free from interfering substances on $\mathrm{Na}$ and $\mathrm{K}$ emission.

\section{Calculations and statistical methods}

Recovery of hemicellulose, cellulose (glucose-polysaccharides in the acid detergent fibre residue) and Klason lignin from wheat bran in the ileostomy contents was estimated as the difference between mean analytical values of period 1 and period 2. Dietary fibre of AACC 
bran was calculated as the mean increase in polysaccharides and Klason lignin in the ileostomy contents when $16 \mathrm{~g} \mathrm{AACC}$ bran was added to the low-fibre diet. For statistical comparison of results from the two periods, Wilcoxon's matched-pairs signed-ranks test was used.

\section{RESULTS}

\section{Diets}

The low-fibre diet was well tolerated by all subjects. The introduction of bran produced problems in one patient only, who complained of a dull abdominal pain but nevertheless he was able to participate in the study.

\section{Wet weight, dry weight ash and water of ileostomy contents}

The weight of ileostomy contents varied considerably between individuals on the same low-fibre diet, but the day-to-day variation in each patient was small. In almost all patients there was an increase in ileal excreta after consumption of bran, although to a varying extent. The wet weight of the night bag contents constituted $25 \%$ of the ileostomy contents per $24 \mathrm{~h}(\mathrm{SE} \pm 2 \cdot 27)$. The difference between the mean wet weight on the two dietary regimens was $94 \pm 31$ ( \pm SE) $\mathrm{g} / 24 \mathrm{~h}(P<0.005)$, (Table 4).

The difference between the mean dry weights of the ileostomy contents between periods 1 and 2 was $9 \pm 1.0( \pm \mathrm{SE}) \mathrm{g} / 24 \mathrm{~h}(P<0.005)$. (Table 4).

The mean values and range of water content and ash in ileostomy contents during the two periods are summarized in Table 4. The difference between the mean values was $85 \pm 30$ $( \pm \mathrm{SE}) \mathrm{g} / 24 \mathrm{~h}(P<0.005)$ for water and $1.3 \pm 0.36 \mathrm{~g} / 24 \mathrm{~h}$ for ash $(P<0.005)$.

\section{Polysaccharide and lignin excretion in ileostomy contents}

Values for the different components of the polysaccharides in the ileostomy contents from periods 1 and 2 are given in Table 5 . After consumption of bran there was an increase mainly in arabinose and xylose (the main hemicellulose components of bran) and glucose. Between 79 and $101 \%$ of the ingested hemicellulose from bran, calculated as polysaccharides of arabinose and $69-106 \%$ calculated as xylose were found in ileostomy contents (Fig. 2). Of the ingested cellulose derived from bran $74-100 \%$ was found in ileostomy contents. The mean recoveries in ileostomy contents of arabinose, xylose and glucose from hemicellulose and cellulose of AACC bran were 88,88 and $89 \%$ respectively. The subjects studied for a $10 \mathrm{~d}$ period did not, however, seem to have a delay in the excretion of polysaccharides from bran. All the bran-polysaccharide was excreted on the day of consumption. Fig. 3 shows the excretion of hemicellulose and cellulose in one of these patients. The other two patients showed a similar pattern The mean ( \pm SE) increase in Klason lignin in ileostomy contents in period 2 was $0.4 \pm 0.08 \mathrm{~g} / 24 \mathrm{~h}$ (Table 6 ).

Analyses of Klason lignin in $16 \mathrm{~g} \mathrm{AACC}$ bran gave a value of $0.7 \mathrm{~g}$. The Klason lignin value of the acid detergent residue of bran was $0.3 \mathrm{~g}$. If this value is used, all Klason lignin could be calculated to appear in the ileostomy contents. A mean ( $\pm \mathrm{SE}$ ) of $0.56 \pm 0.05 \mathrm{~g}$ / $24 \mathrm{~h}$ of starch from the low-fibre diet was found in the ileostomy contents and after supplementation of bran $0.65 \pm 0.08 \mathrm{~g} / 24 \mathrm{~h}$ was found in the ileostomy contents (not significant).

\section{Dietary fibre in bran}

Dietary fibre of AACC bran (increase in polysaccharides and lignin in ileostomy contents) was estimated at $280 \mathrm{~g} / \mathrm{kg}$ of fresh weight or $310 \mathrm{~g} / \mathrm{kg}$ of dry weight (mean values of eight patients; Table 6). One patient received a diet containing Swedish commercial bran and the corresponding value for dietary fibre of Swedish bran was estimated at $380 \mathrm{~g} / \mathrm{kg}$ fresh weight.

Wheat bran contains only small amounts of uronic acids, $10-20 \mathrm{~g} / \mathrm{kg}$ (Theander \& Åman, 


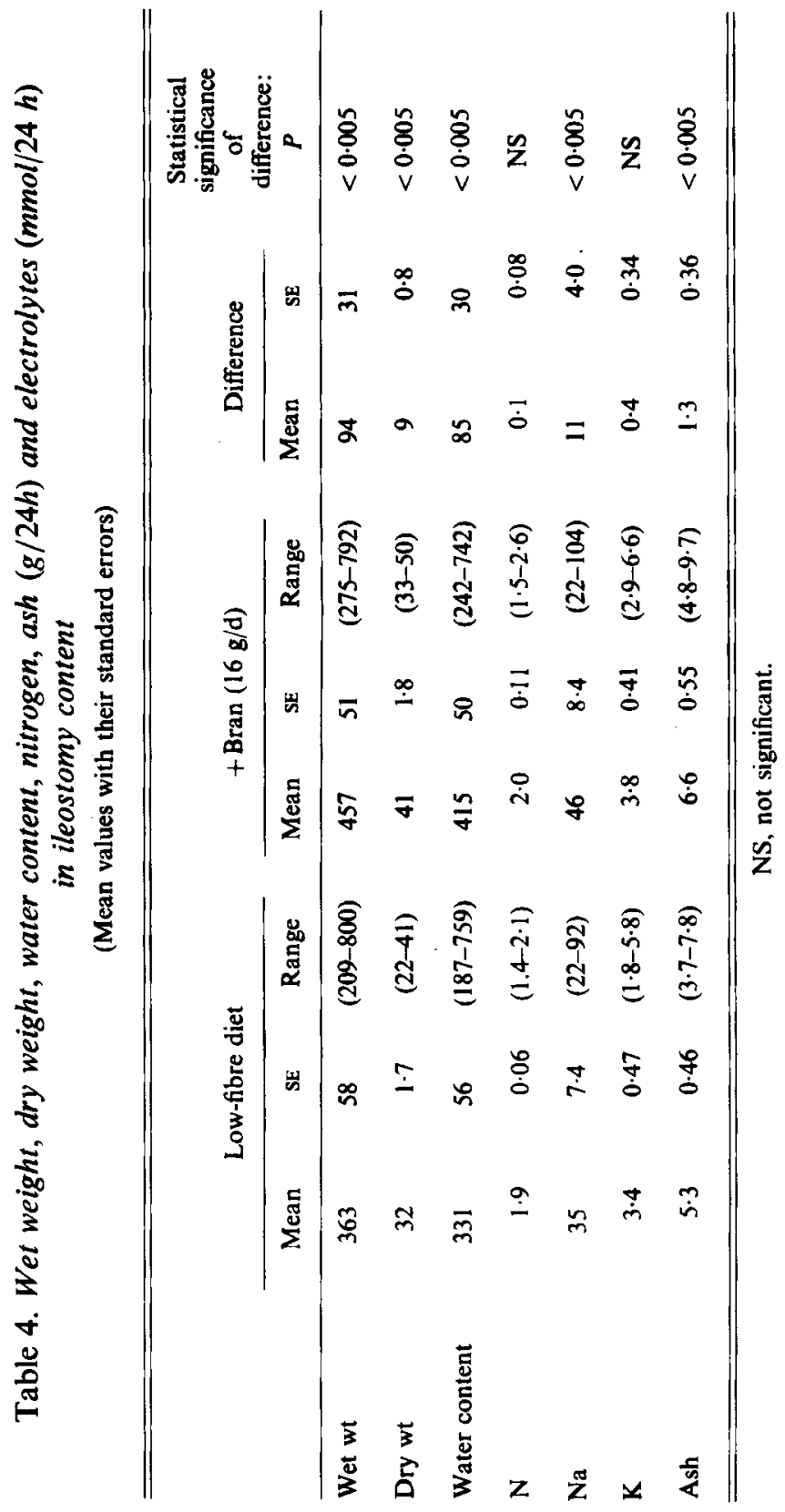




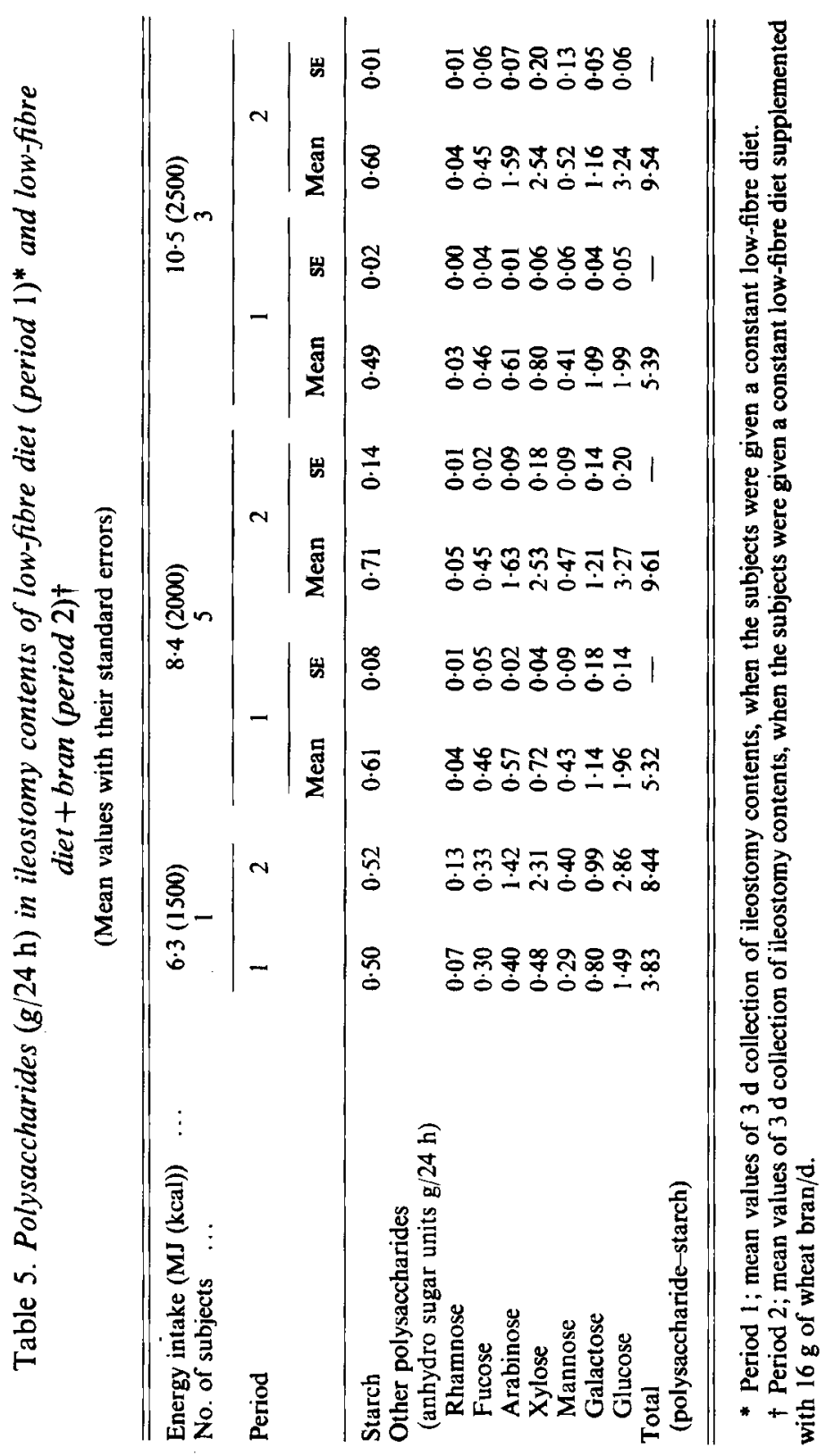




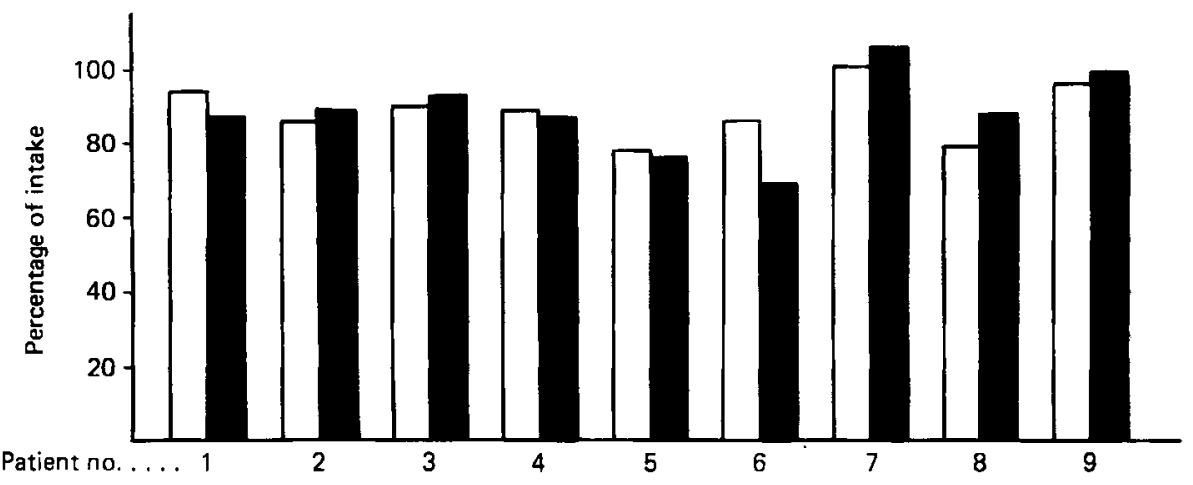

Fig. 2. Recovery of hemicellulose from bran expressed as polysaccharides of arabinose $(\square)$ and xylose

(D) in ileostomy contents of patients with established ileostomies given a low-fibre diet with $16 \mathrm{~g}$ bran $/ \mathrm{d}$.
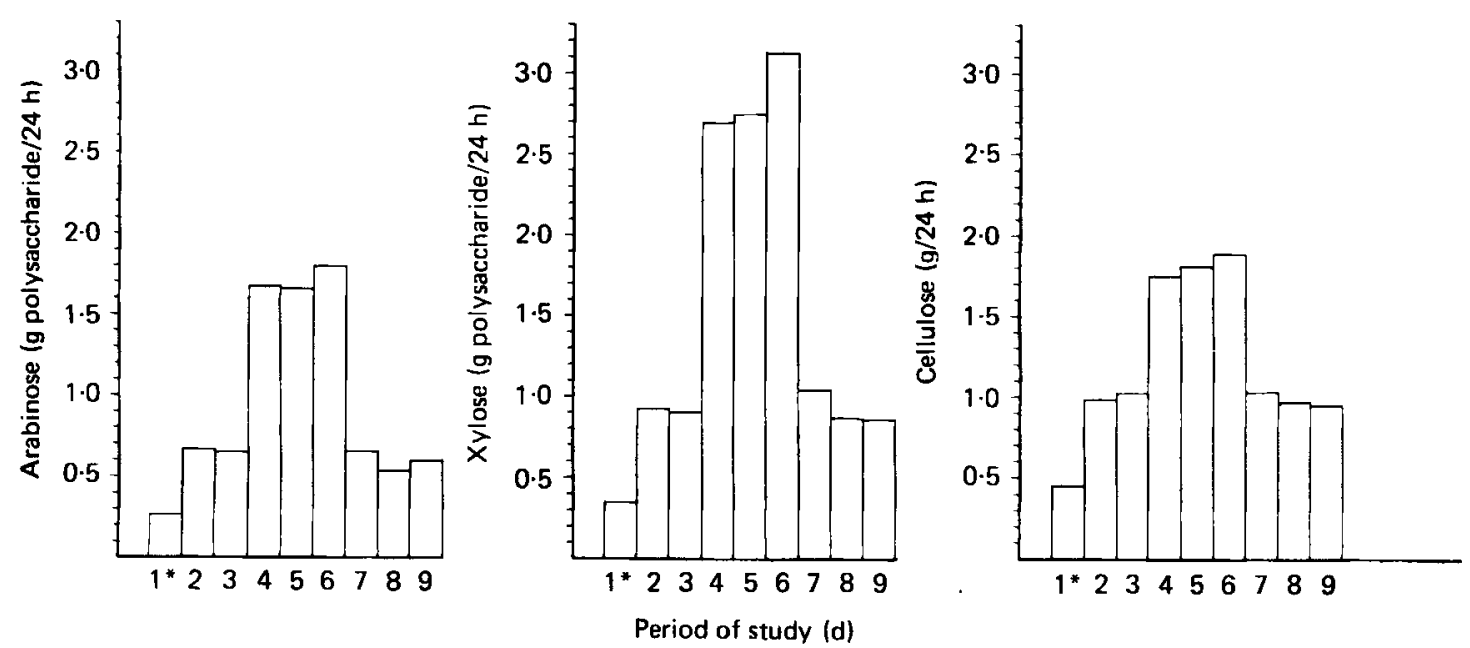

Fig. 3. Fibre components in ileostomy contents of one patient given a low-fibre diet during nine consecutive days with a supplement of bran on days 4,5 and $6 .{ }^{*}$ Lower dietary intake as a result of anaesthesia for treatment of perineal sinuses.

1979), and determinations of uronic acids were not included. The polysaccharide values of ileostomy contents were corrected for starch. Our dietary fibre values of AACC bran should be compared with direct determination of polysaccharides and Klason lignin in AACC bran, which gave a dietary fibre value of $306 \mathrm{~g} / \mathrm{kg}$ fresh weight.

\section{$N$ excretion in ileostomy contents}

The average $\mathbf{N}$ content of the low-fibre diet was $18.7 \mathrm{~g} / \mathrm{d}$. AACC bran and Swedish commercial bran contained $0.4 \mathrm{~g} \mathrm{~N} / 16 \mathrm{~g}$. The mean ( $\pm \mathrm{SE}$ ) excretion of $\mathrm{N}$ in ileostomy contents from period 1 was found to be $1.9 \pm 0.06$ and in period $2,2.0 \pm 0.11 \mathrm{~g} / 24 \mathrm{~h}$ (Table 4). The difference is not significant.

\section{$\mathrm{Na}$ and $\mathrm{K}$ excretion in ileostomy contents}

The mean total $\mathrm{Na}$ content of the low-fibre diet was $113 \mathrm{mmol}$ and the $\mathrm{K}$ content was 66 mmol. AACC bran contained no $\mathrm{Na}$ and $5.9 \mathrm{mmol} \mathrm{K} / 16 \mathrm{~g}$ and the Swedish commercial bran contained $0.1 \mathrm{mmol} \mathrm{Na}$ and $7.4 \mathrm{mmol} \mathrm{K} / 16 \mathrm{~g}$. The mean $( \pm \mathrm{SE}) \mathrm{Na}$ content of the ileostomy contents was found to be $35 \pm 7.4 \mathrm{mmol} / 24 \mathrm{~h}$ in period 1 and $46 \pm 8.4 \mathrm{mmol} /$ $24 \mathrm{~h}$ in period 2 (Table 4). The difference was significant $(P<0.005)$. The $\mathrm{Na}$ excretion 
Table 6. Increase in polysaccharides $(\mathrm{g} / 24 \mathrm{~h})$ of ileostomy contents after consumption of wheat bran $(16 \mathrm{~g} / \mathrm{d})^{*}$

(Values of analyses of $16 \mathrm{~g}$ of wheat bran in parentheses)

\begin{tabular}{lccc}
\hline \hline & AACC bran $\dagger$ & SE & Swedish bran \\
\hline No. of subjects & 8 & - & 1 \\
Rhamnose & - & - & - \\
Fucose & $1.00(1.13)$ & 0.03 & $1.25(1.33)$ \\
Arabinose & $1.74(1.97)$ & 0.08 & $2 \cdot 14(2.45)$ \\
Xylose & $0.08(0.04)$ & 0.03 & $0.05(0.03)$ \\
Mannose & $0.07(0.08)$ & 0.04 & $0.12(0.10)$ \\
Galactose & $1.22(1.37)$ & 0.08 & $1.88(1.52)$ \\
Glucose & $4.11(4.59)$ & - & $5.44(5.43)$ \\
Total polysaccharides & $0.43(0.30)$ & 0.08 & $0.92(0.48)$ \\
Klason lignin & $4.54(4.89)$ & 0.24 & $6.11(5.91)$ \\
Dietary fibre & &
\end{tabular}

* Values for each subject are the difference between mean value of $3 \mathrm{~d}$ collection in period 2 and mean value of $3 \mathrm{~d}$ collection in period 1.

$\dagger$ American Association of Cereal Chemists.

$\$$ The glucose value is corrected for starch.

correlated well with the wet weight of ileostomy contents $(r 0.96)$. The mean ( $\pm \mathrm{SE}) \mathrm{K}$ content of the ilestomy contents was $3.4 \pm 0.47 \mathrm{mmol} / 24 \mathrm{~h}$ in period 1 and $3.8 \pm 0.41 \mathrm{mmol} / 24 \mathrm{~h}$ in period 2 (Table 4 ); the difference was not significant.

\section{DISCUSSION}

The theoretical concept of dietary fibre as formulated by Trowell et al. (1976), only concerns the effect of digestive enzymes and not of bacteria. When using an experimental model with in vivo digestion in ileostomy patients effects of the microflora in terminal ileum must be taken into account. The microflora can multiply and affect the content of the ileostomy bags. This effect has been minimized by the routine of changing ileostomy bags every $2 \mathrm{~h}$ and the content of the removed bag is immediately frozen. In the present study a recovery of $75-100 \%$ of the fibre components of bran indicates that the fermentation was slight.

The amount of dietary fibre in wheat bran was calculated as the increase in polysaccharides and lignin in the ileostomy contents after addition of bran to a low fibre diet. The amount of polysaccharides derived from endogenous material or bacteria in the ileostomy contents was supposed to be constant, in both periods. However, it can not be excluded that the supplement of bran causes a somewhat greater mechanical erosion of the mucosal surface leading to increased losses of endogenous material, but preliminary results suggest no increase in glucosamine and galactosamine, and only a slight increase in uronic acids probably derived from bran.

Another methodological consideration concerns the differences in the colonic inflow which is three times higher in normal subjects (Philips \& Giller, 1973) than in the ileostomized patients (Hill, 1976). These differences affect water and electrolyte absorption but probably not other absorptive processes. Only patients operated on for ulcerative colitis participated in the study. A negligible part of the ileum is removed in such an operation and the absorptive capacity of the small bowel must be considered intact. An advantage of studying ileostomized subjects is that the transit-time through the gut is very short and does not require the long stabilization period necessary when faeces are studied.

In conclusion, we find it highly probable that determination of fibre by using the 
experimental model with in vivo digestion in ileostomy patients comes very close to the theoretical definition of dietary fibre. Almost the same amount of dietary fibre was obtained by analysis of the ileostomy contents as of food, at least of wheat bran. Thus, direct analyses of wheat bran would estimate true dietary fibre.

The mean increase in DM in the ileostomy fluid after addition of bran to the diet was $9 \mathrm{~g}$. Half of this increase constituted dietary fibre components. The increases in starch and nitrogen were small and preliminary results suggest no increase in fat excretion, which was between 1 and $1.5 \mathrm{~g}$ in both periods. However, there was an increased loss of inorganic constituents amounting $1.3 \mathrm{~g}$ and preliminary results indicate an increased loss of low molecular weight sugars. The increase in dry weight ranged between 5.4 and $14.2 \mathrm{~g}$. In the patients with the greatest increase in dry weight there was also an increased nitrogen excretion of $0.3-0.5 \mathrm{~g}$ (although there was no significant increase on the whole group).

That approximately $80-100 \%$ of hemicellulose and $75-100 \%$ of cellulose from bran was found in the ileostomy contents implies that their digestion in the stomach and small bowel is negligible although it cannot be denied that a $10-20 \%$ loss in some patients might be due either to digestion by the gastric juice or to bacterial fermentation in the ileum or both. That digestion by the gastric juice can occur is supported by our in vitro studies on treatment of bran with $0.5 \mathrm{M}$-hydrochloric acid $(3 \mathrm{~h}$ ). It caused a digestion of $10 \%$ of the arabinoseand xylose-containing polysaccharides (Sandberg \& Hasselblad, unpublished observation). The high amount of lignification in bran probably prevents hemicellulose from being digested (Morris \& Bacon, 1977), and the extent of digestion of hemicellulose and cellulose from other sources must be studied in ileostomy patients. According to Holloway et al. (1978) who studied six ileostomy patients on a mixed diet for $10 \mathrm{~d}$, only $27.5 \%$ of the ingested water-insoluble hemicellulose and $84.5 \%$ of the cellulose passed unaltered through the small intestine. Food and ileostomy contents were in this study analysed according to Van Soest (1963). The discrepancy between the results of Holloway et al. (1978) and our results may be due to the fact that the fibre source was not bran but various vegetables and legumes. Their technique did not exclude a substantial bacterial growth and degradation of fibre as the ileostomy bags were not changed frequently and not immediately frozen when removed. However, it is probable that differences in analytical methodology rather than fermentation are the cause of the discrepancy. The analytical methods of Van Soest (1963) are not adequate. Water-insoluble hemicellulose is calculated as the difference between neutraldetergent fibre(NDF) and acid-detergent fibre (ADF) residues, which are both contaminated, NDF with starch and protein and ADF with hemicellulose and pectin (Sandberg \& Hasselblad, unpublished results).

Klason lignin of bran determined as an insoluble residue after hydrolysis of carbohydrate constituents with $\mathrm{H}_{2} \mathrm{SO}_{4}$ (Sarkanen \& Ludwig, 1971) can be expected to contain cutin, tannin-protein complexes and products of the browning reaction besides lignin and might therefore be overestimated (Van Soest \& McQueen, 1973), while the determination of the Klason lignin value on the ADF-residue would underestimate the true amount of lignin as it is partly solubilized in the acid-detergent solution (Gordon, 1978). The amount of lignin found in the ileostomy contents was between the values found for AACC bran, when the two methods were used. The amount of lignin ingested was too small to allow a significant calculation of recovery. However, it seems likely that the main part of bran lignin passes intact through the small intestine. In the present study no significant difference was found in ileal outputs of starch and $\mathrm{N}$ after consumption of bran. Thus, the results do not indicate any inactivation of amylase or proteases by bran. An increase in faecal $\mathrm{N}$ is found when whole-wheat products are fed (McCance \& Glaser, 1948; McCance \& Walsham, 1948; Walker, 1975; Cummings et al. 1976). Our results suggest that the increased faecal $\mathbf{N}$ after fibre supplementation is derived from the large bowel. Results from analyses of mineral 
absorption in these patients will be reported separately. We will continue our study of ileostomy patients by studying the digestion of and physiological effects of citrus pectin.

This study was supported by the Swedish Medical Council (project no. B80-17X-03117-10A) and the National Swedish Board for Technical Development (project no. 79-5226).

\section{REFERENCES}

Andersson, H., Bosaeus, I., Falkheden, T. \& Melkersson, M. (1979). Scand. J. Gastroent. 14, 821.

Bethge, P. O., Rådeström, R., Theander, O. (1971). Svenska Träforskningsinstitutets Meddelande 63B.

Cummings, J. H. (1978). Am. J. clin. Nutr. 31, Suppl 821.

Cummings, J. H., Hill, M. J., Jenkins, D. J. A., Pearson, J. R. \& Wiggins, H. S. (1976). Am. J. clin. Nutr. $29,1468$.

Eastwood, M. A., Kirkpatrick, J. R., Mitchell, W. E., Bone, A. \& Hamilton, T. (1973). Br. med. J. iv, 392.

Eastwood, M. A., Smith, A. N., Brydon, W. G. \& Pritchard, J. (1978). Gut 19, 1144.

Findlay, J. M., Smith, A. N., Mitchell, W. D., Andersson, A. J. B. \& Eastwood, M. (1974). Lancet i, 146.

Food and Agriculture Organization of the United Nations (1970). Amino-acid content of foods and biological data on proteins, 2nd ed. p. 42. Italy: FAO.

Gordon, A. J. (1978). Topics in Dietary Fibre Research, 1st ed., p. 82. G. A. Spiller. New York: Plenum Press. Harvey, R. F., Pomare, E. W. \& Heaton, K. W. (1973). Lancet i, 1278.

Hill, G. L. (1976). Ileostomy: Surgery, Physiology and Management, 1st ed., p. 65. New York and London: Grune \& Stratton.

Holloway, W. D., Tasman-Jones, C. \& Lee, S. P. (1978). Am. J. clin. Nutr. 31, 927.

Jenkins, D. J. A., Hill, M. J. \& Cummings, J. H. (1975). Am. J. clin. Nutr. 28, 1409.

Kirwan, W, O., Smith, A. N., McConnell, A. A., Mitchell, W. D. \& Eastwood, M. A. (1974). Br. Med. J. iii, 187. Larssø,..K., Salomonsson, A. C., Theander, O. \& Åman, P. (1979). Potato Res. 22, 345.

McCance, R. A. \& Glaser, E. M. (1948). Br. J. Nutr. 2, 221.

McCance, R. A. \& Walsham, C. M. (1948). Br. J. Nutr. 2, 26.

Marten, J. F. \& Catanzaro, G. (1966). Analyst, Lond. 91, 42.

Morris, E. J. \& Bacon, J. S. D. (1977). J. agric. Sci., Camb. 88, 327.

Payler, D. K., Pomare, E. W., Heaton, K. W. \& Harvey, R. F. (1975). Gut 16, 209.

Philips, S. F. \& Giller, J. (1973). J. Lab. clin. Med. 81, 733.

Rheinhold, J. G., Faradji, B., Abadi, P. \& Ismail-Beigi, F. (1976). J. Nutr. 106, 493.

Rheinhold, J. G., Nasr, K., Lahimgarzadeh, A. \& Hedayati, H. (1973). Lancet i, 283.

Sarkanen, K. V. \& Ludwig, C. H. (1971). Lignins-Occurance, Formation, Structure and Reactions, p. 7. New York: Wiley-Interscience.

Sawardeker, J. S., Sloneker, J. H. \& Jeans, A. (1965). Analyt. Chem. 37, 1602.

Southgate, D. A. T. (1973). Proc. Nutr. Soc. 32, 131.

Southgate, D. A. T., Branch, W. J., Hill, M. J., Drasar, B. S., Watters, R. L., Davies, P. S. \& Baird, I. M. (1976). Metabolism, 25, 1129.

The Swedish National Food Administration (1978). Food Composition Tables. Stockholm: LiberTryck.

Theander, O. \& Aman, P. (1979). Swedish J. agric. Res. 9, 97.

Trowell, H., Southgate, D. A. T., Wolever, T. M. S., Leeds, A. R., Gasull, M. A. \& Jenkins, D. A. (1976). Lancet i, 967.

Van Soest, P. J. (1963). J. Ass. off. agric. Chem. 46, 829.

Van Soest, P. J. \& McQueen, R. W. (1973). Proc. Nutr. Soc. 32, 123.

Walker, A. R. P. (1975). Am. J. clin. Nutr. 28, 1161. 